\title{
PENGUJIAN KONSENTRATOR CAHAYA TIPE FIXED- MIRROR DISTRIBUTED FOCUS (FMDF) DENGAN PENERIMA BERBAHAN BESI
}

\author{
DIMAS PANGLIMA PUTERA*, OTONG NURHILAL \\ Prodi Fisika, \\ Fakultas Matematika dan Ilmu Pengetahuan Alam, Universitas Padjadjaran \\ Jl. Raya Bandung-Sumedang Km 21, Jatinangor 45363 \\ *email : dimas.panglima@gmail.com
}

\begin{abstract}
Abstrak. Konsentrator cahaya adalah salah satu perangkat kolektor yang mampu mengkonsentrasikan cahaya pada satu titik melalui proses pemantulan dari cermin cekung/parabola. Salah satu tipe konsentrator adalah tipe Fixed-Mirror Distributed Focus (FMDF). FMDF adalah kolektor cahaya dengan posisi dan sudut reflektor tetap. Adapun penerima akan bergerak mengikuti pergerakan titik fokus yang dihasilkan reflektor. Pada penelitian ini telah dibuat FMDF dengan diameter lingkaran parabola $56 \mathrm{~cm}$ dan kedalaman $15 \mathrm{~cm}$. Sebagai reflektor digunakan cermin datar dengan ukuran $2 \times 2 \mathrm{~cm}$ yang ditempelkan pada permukaan parabola. Cahaya yang digunakan berasal dari lampu incandesent 275 Watt yang diatur intesitasnya dengan dimmer. Dalam pengujian alat FMDF dilakukan tiga variasi waktu lamanya penyinaran yaitu 5 menit, 10 menit dan 15 menit untuk setiap sudut datang dan intensitas cahaya. Dari hasil pengujian diperoleh nilai temperatur tertinggi untuk masing-masing variasi waktu sebesar $40,2^{\circ} \mathrm{C}, 41,2^{\circ} \mathrm{C}$, dan $42,1^{\circ} \mathrm{C}$ pada intenitas 2100 lux dengan sudut datang cahaya tegak lurus terhadap permukaan FMDF. Dari hasil perhitungan efisiensi diperoleh nilai efisiensi menurun dengan lamanya penyinaran dan meningkatnya intensitas.
\end{abstract}

Kata kunci : Konsentrator Cahaya, Fixed-Mirror Distributed Focus

\begin{abstract}
A light concentrator is a device that can concentrate light at one point through process of light reflecting from a concave/paraboloid mirror. One type of concentrator is the Fixed-Mirror Distribution Focus (FMDF). FMDF is a light collector with static position and angle. As for receiver, it will move following the the movement of focus point the reflector generate. In this research, a FMDF have been made with diameter of $56 \mathrm{~cm}$ and the depth of $15 \mathrm{~cm}$. as the reflector, it used mirror with the size of $2 \times 2 \mathrm{~cm}$ which glued to the surface of the paraboloid. The light source used is from a 275 watt tungsten incandescent heat lamp that the intensity can be set using dimmer. The testing of FMDF is done with three time variation of irradiation, that is 5 minutes, 10 minutes, and 15 minutes of each angle and intensity variation. From the testing result, was obtained the max temperature of each time variation, that is $40.2^{\circ} \mathrm{C}, 41.2^{\circ} \mathrm{C}$, and $42,1^{\circ} \mathrm{C}$ for intensity of 2100 lux with the incoming light angle perpendicular to the surface of FMDF. From this result, was obtained the efficiency value decrease with the increase of exposure time and intensity given.
\end{abstract}

Keywords : Solar Concentrator, Fixed-Mirror Distributed Focus

\section{Pendahuluan}

Masalah krisis energi yang mulai dirasakan pada saat ini mendorong manusia untuk mencari alternatif sumber energi baru dan terbarukan. Energi surya merupakan salah satu sumber energi yang tidak akan habis (terbarukan) dan menjadi salah satu energi alternatif karena energinya yang besar dan dapat digunakan sebagai sumber energi terbarukan. Negara Indonesia yang terletak di garis khatulistiwa memiliki penyinaran energi surya paling banyak. 
Tulisan ini menyajikan pengujian dari konsentrator cahaya tipe Fixed-Mirror Distributed Focus (FMDF). Konsentrator ini menggunakan prinsip pemantul yang statis dengan penerima yang mampu bergerak. Sistem ini dulu dikembangkan dan diteliti sekitar 40 tahu yang lalu di Crosbytown, Texas[1].

Dibandingkan dengan kolektor surya jenis pelat datar, FMDF menghasilkan temperatur dari sinar matahari yang dikumpulkan pada satu titik fokus lebih tinggi dibandingkan dengan temperatur pada pelat datar [2]. Tetapi dari segi pembuatan alat, FMDF jauh lebih sulit dibandingkan dengan tipe pelat datar. Bentuk dari FMDF yang ideal adalah permukaan cermin cekung yang seragam tanpa sambungan. Namun, membuat FMDF yang seperti ini sangat sulit sehingga FMDF yang dibuat adalah dengan menempelkan potongan-potongan cermin datar pada permukaan parabola dengan kedalaman tertentu.

Pada penelitian ini akan dibuat konsentrator cahaya tipe FMDF. Untuk mendapatkan pantulan yang tajam diperlukan permukaan konsentrator yang homogen atau mendekati homogen sehingga pantulan cahaya jatuh pada titik fokus tertentu secara tajam. Dalam penelitian ini sumber cahaya matahari dan pergerakan matahari dari timur ke barat di simulasikan dengan lampu yang bisa diatur arah datang dan intensitasnya. Untuk mengetahui temperatur masksimum yang dihasilkan diperlukan penerima pantulan cahaya yang dipasang diatas bidang konsentrator.

\section{Deskripsi Alat Dan Metode Penelitian}

Pembuatan alat dibuat berdasarkan sistem FMDF dimana kondisi cermin/reflektor dibuat dengan prinsip spherical mirror dimana pemantul lebih mengikuti bentuk lingkaran dibanding parabolik. Posisi pemantul ditetapkan pada sudut $0^{\circ}$ dan dikondisikan statis. Untuk penerima, terbuat dari batang besi dengan panjang dan terdapat dua sendi untuk masing-masing gerak horizontal dan vertikal. Pada ujung penerima terdapat pelat besi berukuran $5 \times 5 \mathrm{~cm}$ yang berfungsi sebagai bidang penerima. Penerima tersambung dengan penyangga cermin yang berbentuk kotak untuk stabilitas dengan panjang rusuk $40 \mathrm{~cm}$. Acuan ini mengikuti spesifikasi pada jurnal yang berjudul "Field Study of Solar Bowl Under Malaysian Tropical Climate" oleh K. M. Ng, N. M. Adam, B. Z. Azmi, M. A. Wahab, dan M. Y. Sulaiman pada tahun 2010[3].

Untuk penampang lampu dirancang dengan bentuk setengah lingkaran dengan kaki yang berukuran 2 meter x 1,5 meter. Rel untuk lampu dirancang dengan jarijari 1 meter dari titik tengah dari puncak pemantul dan lampu berada pada jarak $80 \mathrm{~cm}$ dari titik tengah puncak pemantul. Hal ini dikarenakan penyebaran sinar dari lampu pada jarak 80 sampai $100 \mathrm{~cm}$ memiliki besar yang hampir sama dengan diameter cermin/relfektor.

Lampu yang digunakan sabagai sumber cahaya pada penelitian adalah lampu penghangat Philips 275 Watt dengan besar emisi infra merah gelombang pendeknya sebesar $34 \%$ dan panjang gelombang maksimal pada 1,2 $\mu \mathrm{m}$. Lampu yang digunakan akan diberikan daya yang berbeda untuk mensimulasikan kondisi matahari berdasarkan waktu dan posisi matahari saat pagi, siang, dan sore. 


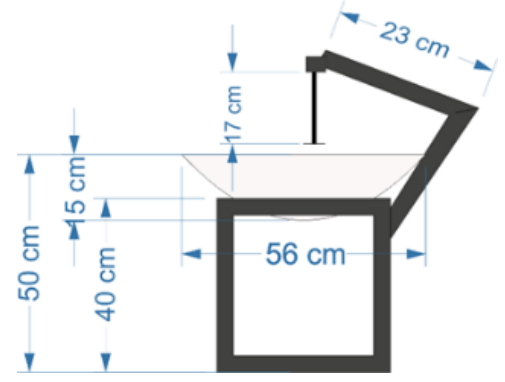

Gambar 1. Skema spesifikasi alat FMDF

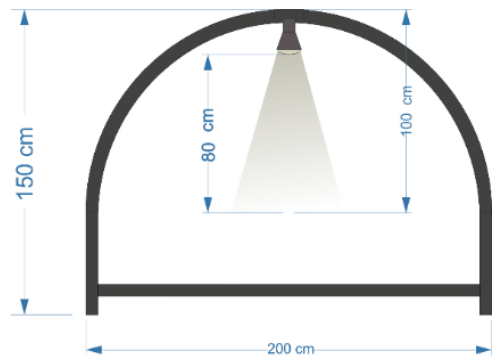

Gambar 2. Skema spesifikasi penyangga lampu

Pengujian alat dilakukan dengan menempatkan FMDF sejajar dengan penyangga lampu, lalu merubah sudut datangnya lampu sebesar $10^{\circ}$ dengan rentang $30^{\circ}$ sampai $150^{\circ}$. Intensitas cahaya pada lampu diubah bersamaan dengan perubahan sudut sebesar 300 lux dengan rentang 300 lux sampai 2100 lux. Setelah lampu mencapai posisi tegak lurus terhadap pemantul (pada sudut $90^{\circ}$ ), intensitas cahaya diturunkan dengan jumlah yang sama ketika dinaikan. Perubahan sudut dan besar intensitas dilakukan seusai rentang waktu penyinaran yang diberikan yaitu 5 menit, 10 menit, dan 15 menit.

\section{Hasil Dan Pembahasan}

Data penelitian berupa nilai suhu terhadap sudut dan intensitas dengan waktu penyinaran tertetu diambil untuk melihat pengaruh sudut datangnya cahaya, besarnya intensitas yang diberikan, serta lamanya waktu penyinaran terhadap suhu yang dihasilkan. Nilai suhu pada penerima dapat dipengaruhi oleh sudut datangnya cahaya. Seiring sudut posisi lampu diubah, posisi berkumpulnya cahaya pada penerima juga ikut berubah karena semakin banyak bidang reflektor yang dapat menerima cahaya. Grafik dari pengukuran suhu dan intensitas terhadap sudut datangnya cahaya dapat dilihat pada Gambar 3 dan Gambar 4. 


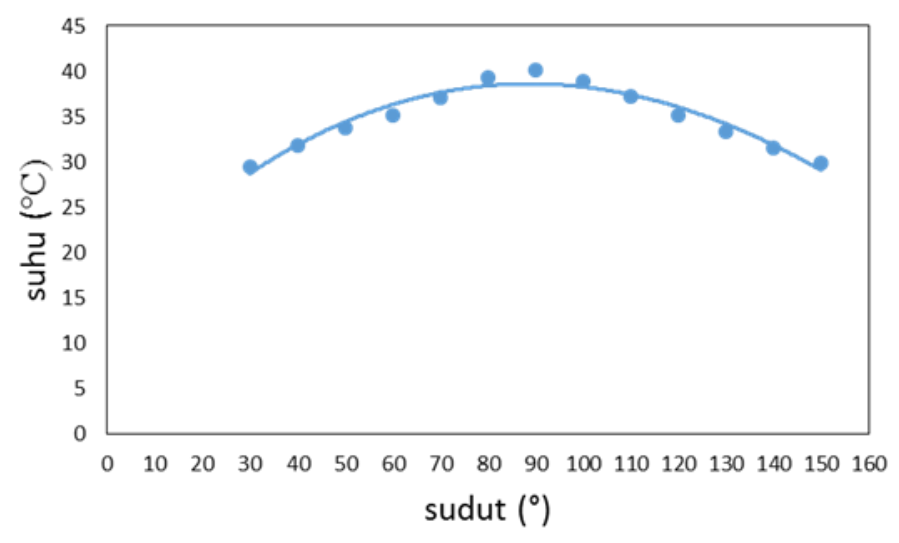

Gambar 3. Grafik perubahan temperatur terhadap sudut datangnya cahaya pada jangka waktu 5 menit

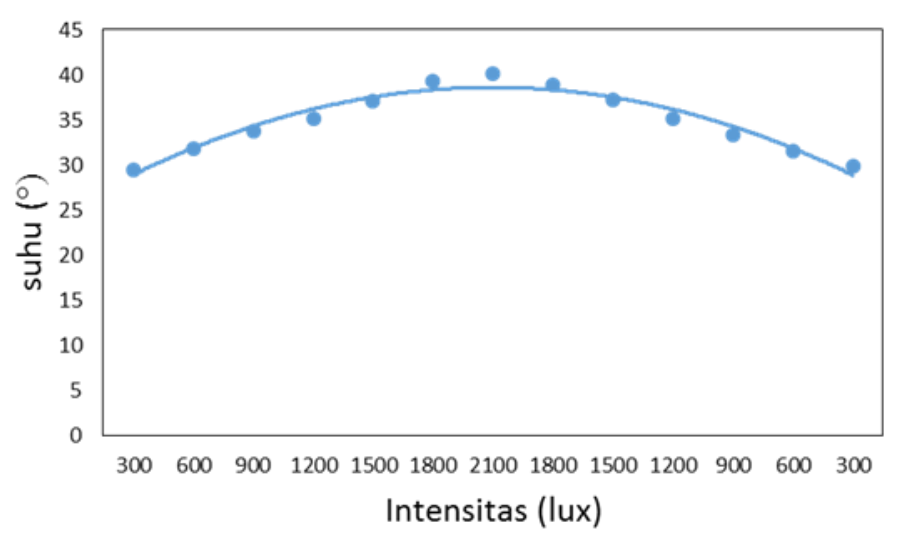

Gambar 4. Grafik perubahan temperatur terhadap perubahan intensitas pada jangka waktu 5 menit

Dapat terlihat bahwa Gambar 3, terlihat bahwa semakin sudut datangnya lampu mendekati $90^{\circ}$, suhu yang dihasilkan semakin membesar dan pada Gambar 4, menunjukan pengaruh intensitas terhadap suhu yang dihasilkan. Semakin besa rintensitas yang pada reflektor, semakin besar pula suhu yang dihasilkan pada penerima karena semakin banyak emisi infra merah yang dikeluarkan. Suhu maksimum yang mampu dihasilkan FMDF pada intensitas 2100 lux adalah $40,2^{\circ} \mathrm{C}$ pada sudut $90^{\circ}$ untuk jangka waktu 5 menit setiap pengambilan data. 


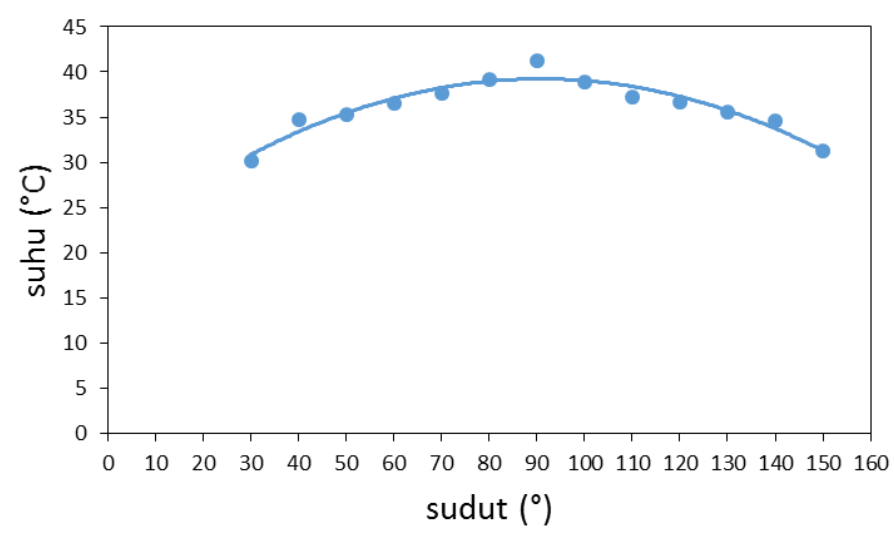

Gambar 5. Grafik perubahan temperatur terhadap sudut datangnya cahaya pada jangka waktu 10 menit

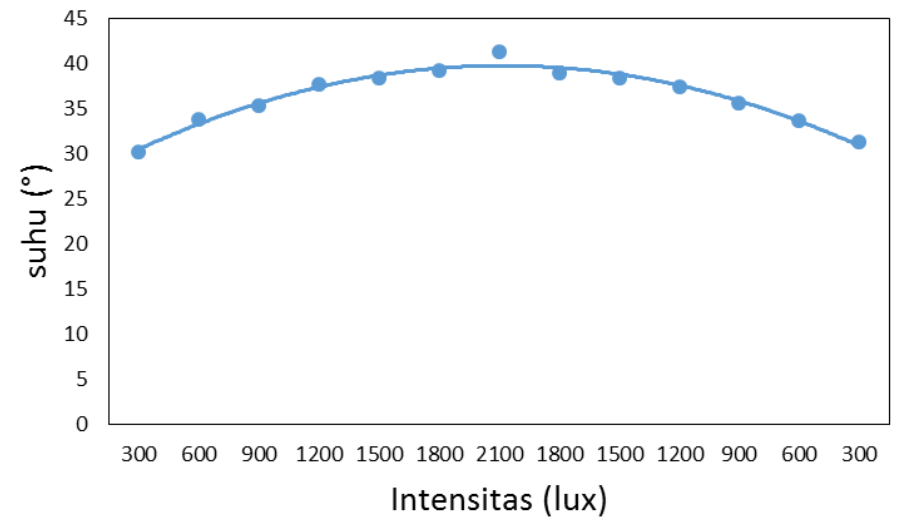

Gambar 6. Grafik perubahan temperatur terhadap perubahan intensitas pada jangka waktu 10 menit

Dapat terlihat bahwa Gambar 5 dan pada Gambar 6 suhu maksimum yang mampu dihasilkan FMDF pada intensitas maksimal juga lebih besar dibandingkan dengan lama waktu penyinaran 5 menit. Suhu maksimum yang mampu dihasilkan FMDF pada intensitas 2100 lux adalah $41,2^{\circ} \mathrm{C}$ pada sudut $90^{\circ}$ untuk jangka waktu 10 menit setiap pengambilan data. 


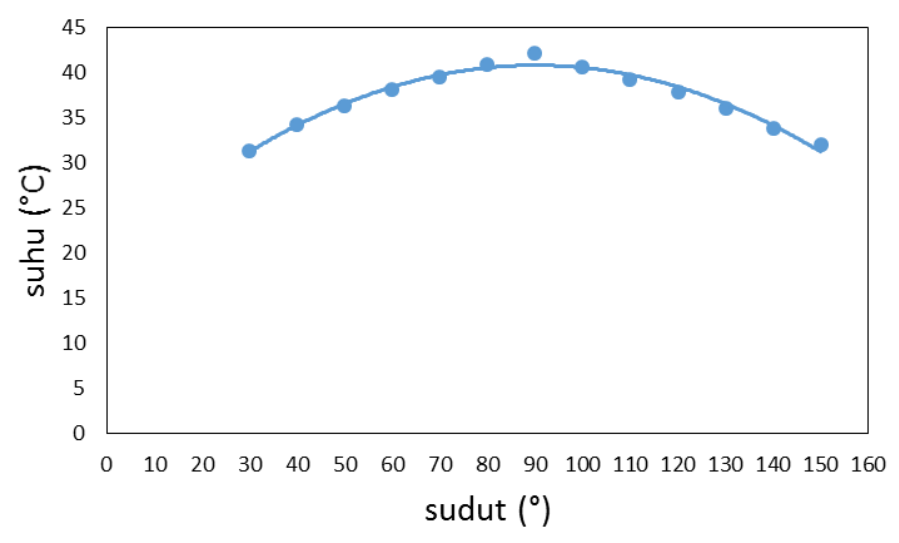

Gambar 7. Graf k perubahan temperatur terhadap sudut datangnya cahaya pada jangka waktu 15 menit

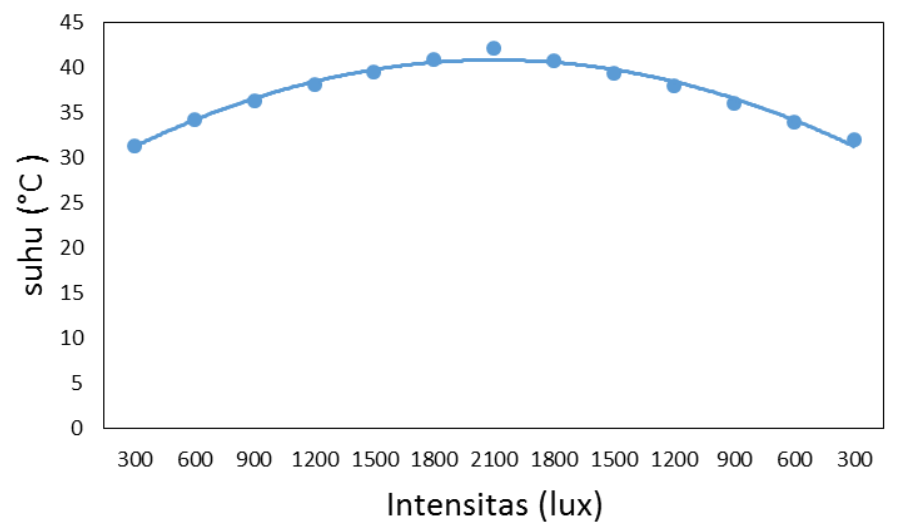

Gambar 8. Grafik perubahan temperatur terhadap perubahan intensitas pada jangka waktu 15 menit

Dapat terlihat bahwa gambar 7 dan pada gambar 8, suhu maksimum yang mampu dihasilkan FMDF pada intensitas 2100 lux adalah $42,1^{\circ} \mathrm{C}$ pada sudut $0^{\circ}$ untuk jangka waktu 15 menit setiap pengambilan data, lebih besar dibandingkan dengan kedua data sebelumnya. Dari ketiga data hasil tersebut dapat terlihat bahwa lamanya waktu penyinaran dapat mempengaruhi peningkatan suhu pada penerima 


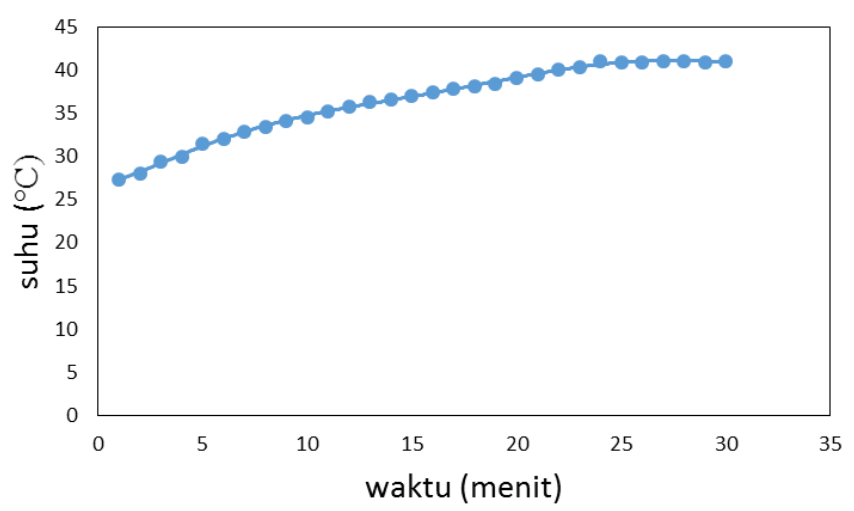

Gambar 9. Grafik perbandingan suhu terhadap waktu pada penerima

Untuk pengambilan data saturasi, penerima lampu di tempatkan pada sudut tetap dan intensitas tetap yaitu sudut $40^{\circ}$ dan intensitas 600 lux, data diambil setiap 1 menit. Pada Gambar 9 bisa dilihat bahwa penerima mengalami saturasi pada waktu 24-25 menit. Hal ini menandakan bahwa penambahan dan pengeluaran kalor pada penerima sudah mencapai titik setimbang dimana jumlah kalor yang masuk pada penerima sama dengan jumlah kalor yang keluar pada penerima. Data ini diambil untuk menentukan berapa lama waktu penyinaran untuk pengambilanhasil suhu .

Sebelum dilakukan perhitungan efisiensi, intensitas yang didapat harus diubah dalamsatuan $\mathrm{Wat} / \mathrm{m}^{2}$, setelah itu harus diukur intensitas pantulannya berapa, dan dari intensitas pantulan itu, jumlah intensitas infra merahnya berapa dari persenan nilaispektrum infra merahnya.



Gambar 10. Grafik efisiensi terhadap intensitas lampu untuk tiap jangkawaktu

Pada Gambar 10, nilai efisiensi penerima untuk jangka waktu 5 menit menunjukan bahwa nilai efisiensi yang dihasilkan paling besar adalah 56,42\% dengan intensitas lampu 300 lux, serta intensitas setelah pemantulan 1290 lux dan nilai efisiensi terkecilnya pada 16,59 \% dengan intensitas 2100 lux, serta intensitas pemantulan 8300 lux. Untuk jangka waktu 10 menit, nilai efisiensi yang dihasilkan paling besar adalah 36,6\% dengan intensitas 300 lux, serta intensitas setelah pemantulan 1290 lux dan nilai efisiensi terkecilnya pada 8,77\% dengan 
intensitas 2100 lux, serta intensitas setelah pemantulan 8300 lux. Untuk jangka waktu 15 menit, nilai efisiensi yang dihasilkan paling besar adalah 29,48\% dengan intensitas 300 lux, serta intensitas setelah pemantulan 1290 lux dan nilai efisiensi terkecilnya pada $6,28 \%$ dengan intensitas 2100 lux, serta intensitas setelah pemantulan 8300 lux.

Terlihat juga pada grafik bahwa, berbeda dengan nilai suhu, nilai efisiensi yang dihasilkan semakin menurun dengan kenaikan intensitas. Hal ini terjadi karena hanya sebagian dari total intensitas lampu yang mampu dipantulkan oleh reflektor dan hanya sebagian dari spectrum lampu dapat menghasilkan panas. Jadi sebagian besar intensitas yang diberikan ke reflector tidak terkonversi menjadi panas, serta karena nilai kapasitansi dari penerima yang kecil, panas yang terbuang kelingkungan juga besar sehingga terjadi energy loss yang tinggi yang berakibat pada kecilnya nilai efisiensi

Selain itu, semakin lama waktu penyinaran yang diberikan, semakin kecil rentang nilai efisiensi yang dihasilkan, dengan waktu 5 menit rentang efisiensinya dari $56 \%$ sampai $16 \%$, waktu 10 menit rentang efisiensinya dari $36 \%$ sampai $8 \%$, dan waktu 15 menit rentang efisiensinya dari $29 \%$ sampai $6 \%$. Hal ini dapat terjadi karena lama waktu penyinaran dapat memperbesar rentang suhu yang dihasilkan dan jika rentang suhu yang dihasilkan lebih besar, maka nilai efisiensi yang dihasilkan akan semakin kecil. Dari data efisiensi alat, dapat terlihat bahwa perbedaan sudut datangnya cahaya, intensitas yang diberikan, dan waktu penyinaran dapat mempengaruhi suhuter tinggi dan nilai efisiensi yang dihasilkan.

\section{Kesimpulan}

Telah dibuat kolektor surya tipe FMDF dengan diameter $56 \mathrm{~cm}$, kedalaman $15 \mathrm{~cm}$, luas permukaan pantul $0.33 \mathrm{~m}^{2}$, sudut efektif dari $30^{\circ}$ sampai $180^{\circ}$ dan proyeksi fokus pada jarak 16,8-17 $\mathrm{cm}$ dari permukaan. Hasil pengujian menunjukkan bahwa untuk penyinaran dengan lama waktu 5 menit, diperoleh suhu tertinggi $40,2^{\circ} \mathrm{C}$ dan nilai efisiensi terbesar $56 \%$ dengan rentang efisiensi dari $56 \%$ sampai $16 \%$. Untuk jangka waktu 10 menit, diperoleh suhu tertinggi $41,2^{\circ} \mathrm{C}$ dan nilai efisiensi terbesar 36\% dengan rentang efisiensi dari 36\% sampai $8 \%$. Untuk jangka waktu 15 menit, diperoleh suhu tertinggi $42,1^{\circ} \mathrm{C}$ dan nilai efisiensi terbesar $5,8 \%$ dengan rentang efisiensi dari $29 \%$ sampai $6 \%$. Lama waktu penyinaran berpengaruh terhadap temperatur yang dipantulkan dan kinerja FMDF.

\section{Daftar Pustaka}

1. The Solar Bowl. (Diakses dari https://www.auroville.org/contents/3294 Akses: 3 September 2017 Pukul 10.37 WIB).

2. Darling, David, Stationary Concentrating Collector, (Diakses dari http://www.daviddarling.info/encyclopedia/S/AE_stationary_concentrating_col lector.html, Akses: 5 September 2017 Pukul 09.23 WIB)

3. K. M. Ng, N. M. Adam, B. Z. Azmi, M. A. Wahab, M. Y. Sulaiman, Field Study of Solar Bowl Under Malaysian Tropical Climate, Wseas Transactions on Environment and Development, 2010 